\title{
Alice Amsden's impact on Latin America
}

\author{
HELEN SHAPIRO \\ JUAN CARLOS MORENO-BRID*
}

On March 15 2012, we lost Professor Alice Amsden, a great intellectual power in development economics. Her work was systematically marked by creativity, originality, relevance and her fearless commitment to always speak truth to power both in academic as well as in policy-making arenas. This In Memoriam concentrates on just one part of her great intellectual legacy: her impact to better understanding Latin America's development challenges, obstacles and policy options. Our paper focuses on three broad areas of her main influence in the region: the role of transnational corporations, the importance of manufactured exports for development, and industrial policy. As we here argue, in all of them, her work is and continues to be a substantial contribution to knowledge that policy makers will be well advised to take into account if the region is to finally enter a path of structural transformation and sustained economic and social development.

Keywords: industrial policy; export of manufactured goods; Latin America.

JEL Classification: O1; O12.

\section{INTRODUCTION}

In the early 1990s, one of us was fortunate to attend a small conference that brought Latin American technocrats - mostly from Finance Ministries - to Tokyo so that they could exchange ideas with their Japanese counterparts, as well as with Japanese academics. It was part of the response to the enormous challenge provoked by the work of Alice Amsden (1944-2012) and others, which drew Latin American attention east and spawned innumerable conferences and publications comparing the two regions. Remember that at the time, Latin America was just

\footnotetext{
* Respectively, Sociology Department, University of California Santa Cruz. E-mail: hshapiro@ucsc.edu; ECLAC - Economic Commission for Latin America and the Caribbean. E-mail: juancarlos.moreno@ cepal.org. This paper was originally presented at a symposium commemorating Alice Amsden held at MIT, Oct. 19, 2012.
} 
beginning to resume its economic expansion, albeit at a moderate pace, finally leaving behind its "lost decade" detonated by the international debt crisis in 1981 .

This particular meeting was a study in contrasts. With the exception of the Brazilians, the Latin Americans were younger and virtually all of them had been trained in the US. They were focused mostly on macro stabilization and strongly supportive of trade liberalization, privatization and restricting the role of the state in the economy. They saw no relevance in learning about Japan's economic history and thought the idea of state intervention, particularly industrial policy, was antiquated and had been debunked. They considered the state as the source of all "distortions" associated with the region's legacy of import substituting industrialization that ended in the late 1970s - again, excluding the Brazilians. They kept asking how it was that Japan managed to save so much, to which the Japanese kept responding that it was because they grew so fast and invested so much, and so it went, in circles.

This intellectual clash was emblematic of the different worlds and contrasting paradigms that they each reflected, a microcosm of what Alice would write about in her subsequent work. Latin America, with its low population density, abundant natural resources, and potentially dynamic domestic market - due to its relatively high wages and strong job creation in the urban areas absorbing workers from the rural sector - followed a more inward oriented development strategy. This was particularly true of the medium and large sized economies in Latin America, but also of the small Central American ones that managed to create a Common Market to widen subregional demand for their local products. Most Latin American countries sought to emulate the US, rather than Japan. In fact the experience of Japan and, for that matter, the rest of South East Asia, was in general outside the radar of Latin American policy makers.

Nevertheless, as Alice's pioneering work strongly proved, for Latin America there was and there still is much to learn from Asia's development strategy. Indeed, her legacy lives on in its academic and policy-making arenas, even if she is not always given direct attribution. She forced all of us to question our assumptions on a range of topics. And by all of us, we don't mean only mainstream economists, but also those of us who define ourselves as heterodox in one way or another. This paper focuses on three broad areas of her influence: (1) the role of transnational corporations (TNCs); (2) the importance of manufactured exports; and, last but not least, (3) industrial policy.

\section{TRANSNATIONAL CORPORATIONS}

To put it bluntly, she hated them, at least the US and European varieties. In her mind, they were worse than useless, but had a malign effect on development. Their dominance in manufacturing was a primary cause of Latin America's stunted development. She was not the first to question TNCs' contributions to development or to lay out their nefarious effects. There is a long history of scholarship, policies, 
and political conflict related to their role in Latin America. In response to the mainstream view that they were beneficent sources of capital, technology, managerial expertise, and linkages, many authors documented the widespread abuse of transfer pricing, inappropriate technology transfer and consumption patterns, excessive subsidization, high import content of production, supply chain manipulation, and political interference.

Alice's criticisms came from a different place, though. She didn't focus so much on the macro or balance-of-payments ramifications. And she was downright scornful of appropriate technology arguments - none of that "small is beautiful" stuff for her. Instead, she combined an unapologetic anti-imperialist outlook with her insight into the importance of learning and technological capabilities at the firm level. Firms' ability to shift from primary resources to knowledge-based assets was the key determinant of long-term growth. And it was critical that firms in mid- and high-tech sectors be dominated by domestic, rather than foreign firms (Amsden, $2009 \mathrm{~b}$ ). Her central argument was that TNCs prevent such learning at the national level. In these key sectors with barriers to entry, they get first mover advantage and crowd out national firms. Subsequently, they maintain all important activities, including R\&D, at home (Amsden, 2001, ch. 8; Amsden, 2007).

In her view, this was especially the case in Latin America, and a key explanation for the region's weak performance compared to that of East Asia. TNC investment arrived earlier in the region's industrialization process, and as a share of manufacturing output, was larger than the Japanese share in Korea or Taiwan (Amsden, 2001). More importantly, in contrast to East Asia, the TNCs never left. "There was no disruption in the ownership of productive assets. FOEs (foreignowned subsidiary of a multinational) were everlasting [...] Given this continuity, any aspiring nationally owned Latin American POE (private nationally owned enterprise) had to confront these dinosaurs in its own backyard" (Amsden, 2009b: 416-417). In her view, the discontinuities in Asian property rights made it easier to provide government support to national firms.

Alice was prescient in this regard. She was talking and writing about these issues long before anyone else, and understood that technology was about process and wasn't simply another "factor of production". Even the large literature on the bargaining capacity of the state to shape foreign investment strategies did not focus on managerial expertise, shop floor learning, and technical training, the heart of late industrialization in her view. She no doubt helped motivate the more recent concern in Latin America about falling into the "middle income trap" and a renewed emphasis on technological capabilities.

As she predicted, studies have shown that R\&D expenditure by TNCs in the region is virtually nil and spillovers are limited. This is the case despite the return of large investment flows to the region that started in the 1990s, particularly to the larger countries. Their control of the most dynamic manufacturing sectors has increased since liberalization, with troubling consequences for technological upgrading (ECLAC, 2012a; Garrido\&Peres, 1998; Kosakoff, 2000; Shapiro. 2007). Moreover, in some countries like Mexico, the financial sector — critical for develop- 
ment - has become virtually de-nationalized as local banks were bought by large foreign banks and financial conglomerates, and the public sector's development banks have been acutely weakened or dismantled (Moreno-Brid\&Ros, 2009). This relatively new and massive presence of foreign banks has produced mixed results. Total bank credit has risen sharply from a total average equivalent to $47 \%$ of the region's GDP in 2000 to $71 \%$ in 2010, and the new financial entities are well capitalized (ECLAC, 2012b). However, the new credit has been heavily concentrated on consumption purchases rather than on productive investment projects, and tends to be short term. In addition, these new foreign banks have not compensated for the disappearance of most development bank credit that was largely allocated to infrastructure and private investment projects.

Moreover, the bulk of FDI in Latin America has not gone into technologically dynamic sectors. Rather, it has gravitated towards services and raw material-intensive sectors such as oil refining, food, textile, and pulp and paper. In 2011, Latin America received US\$ 153 billion in FDI (10\% of the worldwide total). Brazil was the main recipient with US\$ 68 billion followed by Mexico (US $\$ 20$ billion) and Chile (US\$ 18 billion). These amounts reached the equivalent of 7\% of GDP in Chile, but less than 3\% in Mexico and in Brazil. On average, more than half of these flows went to service sectors, followed by natural resource-intensive sectors, a pattern unchanged since 2001. The manufacturing industry was a significant recipient of FDI in Brazil, Mexico and Central America, where it got close to $40 \%$ of its respective total, in marked contrast to South America where less than $10 \%$ of total FDI went to manufacturing. Significantly, only $3 \%$ of new FDI in manufacturing was in high technology sectors (down from $8 \%$ in $2006-10$ ), and only $34 \%$ in medium-high technology ones. This pattern is in stark contrast to Asia's, where $80 \%$ of foreign investment projects are in high or medium-high technology sectors. Only Brazil, with $5 \%$ of the worldwide total, was a major destination for R\&D intensive projects of this type (ECLAC, 2011b, 2012c). Domestic investors - both public and private - displayed a similar aversion to high-tech. In fact, not one country in the region met the regional goal of investing $1 \%$ of GDP in R\&D.

As a result, and as Alice predicted a decade ago, Latin America's technological gap with East Asia and with the OECD continues to widen according to a variety of indicators, such as R\&D spending in manufacturing and the private sector's share in R \&D expenditure. A study by the Inter-American Development Bank found that East Asia, excluding China, spent five times more on enterprise-financed $\mathrm{R} \& \mathrm{D}$, and that the gap was expected to grow over time (Lall, Albaldejo\&Moreira, 2004, p. 43). This challenge and the disappointing performance of TNCs with respect to R\&D have led a number of organizations, including ECLAC, to question the efficacy of Latin America's liberal policies towards FDI. They advocate, in line with Alice, a more selective approach to FDI to favor projects that strengthen local R\&D capacity, foster linkages with domestic industry, and promote the country's systemic competitiveness.

Her work in this field leaves us with interesting counterfactual questions regarding Latin America and TNCs. If US and European TNCs instead had been 
Japanese, which in her account trained Korean and Taiwanese workers and left other important capabilities, would the outcome have been different? Essentially, was Latin America's problem the permanence of TNCs or having the wrong ones? Even if they could have somehow nationalized TNC subsidiaries, could they have managed? Moreover, now Latin America has some locally generated TNCs that are important players in international markets - the so-called translatinas - such as CEMEX, Petrobras and Telmex. What is their importance for overall national or regional economic development? To what extent does transnational activity boost or hinder domestic investment in their country of origin? Finally, is Latin America's destiny structurally pre-determined by its history and the dominance of TNCs, as Alice implied, or can economic outcomes and TNC behavior be shaped by economic/political actors and policies? Answers to these questions are ultimately related to the relation between FDI and overall fixed capital formation, i.e., investment. What are the determinants of investment? What are their main obstacles and how can they be removed? What are the reasons that in some countries, at certain historical moments, the elites form coalitions that put in place a successful agenda for economic development? These are important questions that Alice's contributions help us to understand.

\section{MANUFACTURED EXPORTS}

At first, mainstream economists attributed East Asia's growth rates to its export orientation. The flip side of this was an obsession with the so-called anti-export bias of Latin America's import-substitution policies, which were blamed for inefficient, non-competitive firms, rent-seeking behavior, and ultimately, to macro imbalances, slower growth, and recurrent balance-of-payments crises. Particularly post-debt crisis, export promotion in the context of broader trade liberalization was presented as a panacea to all that ailed Latin America. This was one aspect of the East Asian experience that economists chose to replicate in Latin America.

Alice, too, based on her profound knowledge of the Asian experience, appreciated the key role manufactured exports played in development, but she had a much more nuanced and sophisticated analysis of what exports meant to firms, her unit of analysis, the relation of exports to domestic markets, and the policies to promote them. In contrast to the Washington Consensus perspective, she didn't use exports as another bludgeon to use against import substitution policies.

In fact, she was one of the first to argue against presenting a false dichotomy between import substitution and export promotion. She showed that they complemented each other and demonstrated that for firms, export success was predicated on import substitution: "Only one simple story tends to repeat itself: behind the rise of every export was an earlier import substitution investment" (Amsden, 2009c). Import substitution created the capacity to export, including learning and scale. Even if the exports per se were not the same as the import-substituting products, they were produced by the same firms. 
She argued that East Asia's export success could not be duplicated simply by changing trade policy, since it did not result from market incentives. Rather, it reflected a whole series of state-business relations and institutions, including performance standards and monitoring. "Simply exporting proved to be too tough a first step for firms lacking original know-how or connections to advanced country markets, no matter what the enlightenment fathers and market theorists said. Subsidization of domestic capacity was the only practical policy [...]" Liberalizing trade, in the absence of the entire package, would subject domestic firms to an international competition that they couldn't survive: "At market prices, many poor countries had no comparative advantage at all" (Amsden, 2001).

This is an important message that simply got no attention from Latin American governments through most of the 1990s as they instituted drastic macroeconomic reforms to expose their domestic product and financial markets to foreign competition. Signing free trade agreements practically replaced soccer as the region's most favored internationally competitive activity. In contrast to East Asia, Latin American governments equated export promotion with trade liberalization and deregulation. Thus, industrial policy was abandoned and sectorial credit or fiscal facilities to promote international competitiveness of selected activities were cancelled. The importance of exports as key to development was recognized, but the means adopted to promote them - and against Alice's best advice - were very much in line with orthodox economics. In response to liberalization, local prices were expected to align with international prices and reflect domestic competitive advantage. This was the opposite of Alice's famous dictum to "get prices wrong" to shift the economy from a growth path based on static comparative advantages of scantly qualified labor abundance to a dynamic one based on high tech processes.

Her skepticism about the means by which exports were then promoted in most of Latin America did not mean that she thought exports were unimportant. On the contrary, she wrote about her concern that Latin American countries, emulating the US, focused too exclusively on their domestic markets and did not have dedicated public institutions to promote exports. While many sectors were not the inefficient dinosaurs described by import substitution's critics, she thought that it was harder to become competitive behind tariff walls and that important learning and scale economies were gained through exporting. She also pointed out that, in contrast to the US, Latin American countries had no first-mover advantages or technological mastery to exploit in their protected domestic markets (Amsden, 2001).

Perhaps we should have paid closer attention. For in response to the simplistic export promotion politics that emanated from Washington, many non-mainstream economists argued that exports were not so critical, at least for the larger Latin American countries. "Fallacy of composition" arguments were often presented (Helleiner, 1992), as were arguments about how Latin America's relatively high wages compared to East Asia precluded the region from industrializing in this way.

This response may have been an overreaction. If you look at Latin American exports today, especially during and after the 2003-08 boom, they are concentrated in natural resource based products, not those sectors with the greatest po- 
tential for productivity growth, technological upgrading and strengthening of backward and forward linkages. Indeed, in 2011, ten commodities and mineral products (coffee, fish, meat, fruit, sugar, soy beans, gas, iron, copper and oil) account for more than $40 \%$ of Latin America's total exports. In Mexico, Latin America's alleged success story in reorienting domestic production to foreign markets, high-tech manufactured goods do represent more than $80 \%$ of total exports. However, a vast number of these exports are essentially produced in maquiladoras that locally assemble imported inputs with scant use of domestic intermediate products or raw materials (Moreno-Brid et. al., 2005). In reality, they are high-tech exports produced through rather simple assembly processes that neither rely on local R\&D capacities nor have significant backward or forward linkages with domestic suppliers.

This is also in contrast to global trends, where the fastest growth rates are in high and medium technology exports, produced by global firms that heavily invest in $R \& D$ with techniques that are far above mere assembly activities. Given the rise in high tech as a share of world trade, export success is increasingly associated with a country's ability to persistently move into these product categories, as Alice long argued. Currently, the fastest growing countries are shifting into high tech exports, while Latin American exports reflect its manufacturing profile more generally, which is dominated by low and medium tech products. Moreover, Latin America's sharply improved terms of trade and commodity boom in recent years - closely linked to China's expanding demand - has re-primarized even more the region's export basket. Whether this boom will persist or whether it will collapse and bring about a new balance-of-payments crisis in the region, confirming Prebisch's nightmares, is an open question.

\section{INDUSTRIAL POLICY}

The third, and most significant, legacy of Alice's work in the Latin American context has to do with industrial policy. She and others challenged prevailing orthodoxy about the reasons for East Asia's success - that it wasn't the result of free markets but of state intervention and industrial policy. Ultimately, this created space for industrial policy in Latin America, but it first generated a firestorm. We suppose one could say that the attempt to prove her wrong, like imitation, was a high form of flattery. Even in retrospect, the amount of verbiage devoted to this pursuit is amazing and an indicator of how much was, and is, at stake.

When the evidence that East Asia was not a story of free markets became insurmountable, more effort was devoted to show why the East Asian strategy could not be replicated to other regions. In the process, two implicit views - one unproven, one absurd - became dominant. The first was the widely asserted assumption that government or institutional failure was inherently worse than market failure. The interpretation of the debt crisis as a direct consequence of Latin America's development strategy based on trade protectionism and state-led industrialization helped sustain this attitude. The second was that in the absence of 
market-distorting state interventions, a rent-free society would somehow prevail (Shapiro\&Taylor, 1990; Shapiro, 2011). In practice, what this meant was that the East Asian model would not be applicable to Latin America. Within academic and policy-making circles, just the mention of rent seeking was enough to shut down any meaningful discussion of industrial policy.

Alice herself acknowledged the risks associated with industrial policy. Indeed, she emphasized that reciprocity and monitoring to discipline the private sector were keys to South Korea's success. However, she never worried about rents per se or thought that they were the result only of state interventions. She never imagined a counterfactual, rent-free world that a free market would deliver. To the contrary, rents were at the heart of her analysis. Successful firms created and maintained barriers to entry and the rents associated with them. They drove technological change. The whole purpose of a firm's drive for technological upgrade was to get rents for as long as possible. In late industrializing countries, firms needed rents from subsidies and protection to sustain the costs associated with R\&D. Interestingly, much development theory now supports the view that firms will invest in $R \& D$ only if assured that rents won't dissipate from foreign competition, particularly when the technological gap is large. This hasn't led to a shift in policy recommendations (Shapiro, 2007).

Alice emphasized that rent creation was necessary, but not sufficient, since what mattered most was what firms did with the rents they received. In this respect, Latin America has done relatively poorly, particularly with respect to TNCs. As mentioned earlier, governments negotiated with them over investment, taxes, domestic content, and even exports, but less often on R\&D or managerial expertise. The academic literature also failed to emphasize this weakness (and we include ourselves here).

That aside, the obsession with rents and institutional failure as well as a misperception of state intervention as the root cause of Latin America's economic collapse in the early 1980s created an ideological barrier in the region to industrial policy. The epitome of this reaction was in Mexico, where the minister of trade in the mid 1990s publically stated that "the best industrial policy is no industrial policy at all". In retrospect, the radical shift in emphasis from markets to institutions proved to be a huge distraction, and its legacy lives on today in most of the region, more than 20 years later.

This has been the case even as fiscal constraints have loosened and more sympathetic governments have taken office. While Latin America's shift to the left in the last ten years has changed the rhetoric on development, it has not led to major policy changes. Due to years of weak growth performance despite abated inflation and reduced public deficits, it became common to question the benefits of the Washington Consensus. Market reforms are now perceived as having gone erroneously too far in reducing the role of the state in the economy to the detriment of growth, a conclusion that Alice certainly shared. However, in practice, most new governments in the region have maintained rather orthodox macroeconomic regimes based on austere fiscal and monetary policies, inflation targeting, and very 
contained public deficits (on average not above $3 \%$ of GDP). At the same time, there has been a growing consensus that free trade agreements, notwithstanding their merits in expanding commerce, have been unable to push the region onto a path of robust economic expansion and development. Pari passu there has been an increasing recognition of the merits of industrial policy as a valuable tool to promote structural change and economic growth.

These last two points - the limitations and even potentially harmful effects of trade agreements and the need for industrial policy - could have been taken from pages in Alice's work. However, her view of industrial policy was of a much more active intervention than the one generally put in place. The region has finally moved away from the dictum that "the best industrial policy is no industrial policy at all”, but is miles away from having an Asian type of industrial policy. Indeed, in general we do not see the state allocating resources to boost local industry's dynamic comparative advantages - as opposed to the static ones given by current market prices - and strengthen the long term international competitiveness. Contrary to Alice's recommendations, the use of fiscal and financial incentives or the adoption of regulations to promote specific industrial sectors is more the exception than the rule. This situation is aggravated by the persistent trend of real exchange rate appreciation in the context of financial liberalization, vast and unstable movements of short term capital flows, and the boom in commodities, all of which tend to crowd out the manufacturing sector.

Up until now, the significant exception is Brazil. No wonder it drew Alice's attention. Starting with Lula, the revived developmental state has explicitly adopted a long-term strategy to promote specific activities. Without carrying out a detailed analysis of the policies involved, let us just stress that a key tool is its development bank (BNDES). Indeed, it has provided massive amounts of financial resources with preferential terms to promote key industrial activities. Not surprisingly, a number of Brazilian firms are becoming important players in international markets. One of them is certainly Petrobras, which through massive state support, has become a major actor in the world oil and petrochemical industry and increasingly relies on its own R\&D. The contrast with Mexico on both grounds is dramatic, as the rise of Petrobras and BNDES has been accompanied by a substantial decline of Pemex and of the national development bank, and by the Mexican State's explicit decision to severely restrict Pemex's investment potential and reduce the scope and scale of Nafinsa and Bancomex, once its pillars of development finance (Moreno-Brid\&Ros, 2012).

\section{A FINAL THOUGHT}

We got to know Alice almost 25 years ago, as we were arriving in the Boston area. She was one of the few women working on economic development - one of the few women economists, period. For all her bluster, she was always supportive and encouraging. She was fearless, and always spoke truth to power. Many years 
ago, during an Economic History Association panel, Joel Molkyr said that if Alice Amsden didn't exist, the economic profession would have had to invent her. Sadly, now we will have to.

\section{REFERENCES}

Amsden, Alice H. (2010). "Say’s law, poverty persistence and employment neglect.” Journal of Human Development and Capabilities, 11(1), 2010.

Amsden, Alice H. (2009a). "Does firm ownership matter? POEs vs. FOEs in the developing world," in Ravi Ramamurti and Jitendra V. Singh, eds., Emerging Multinationals in Emerging Markets, Cambridge University Press: 64-78.

Amsden, Alice H. (2009b). "Nationality of firm ownership in developing countries: Who should crowd out whom in imperfect markets?” in Mario Cimoli, Giovanni Dosi and Joseph Stiglitz, eds., Industrial Policy and Development, Oxford University Press: 409-423.

Amsden, Alice H. (2009c). “The wild ones: industrial policies in the developing world," in Narcis Serra and Joseph E. Stiglitz, eds., The Washington Consensus Reconsidered. Oxford: Oxford University Press.

Amsden, Alice H. (2007). Escape from Empire: the Developing World's Journey through Heaven and Hell, Cambridge: MIT Press.

Amsden, Alice H. (2001). The Rise of "The Rest": Challenges to the West from Late-Industrializing Countries, Oxford: Oxford University Press.

Amsden, Alice H. (1989). Asia's Next Giant: South Korea and Late Industrialization, Oxford: Oxford University Press.

Chudnovsky, Daniel et. al. (1996). Los Limites de la Apertura: Liberalizacion, Reestructuracion Productiva y Medio Ambiente, Buenos Aires: Alianza Editorial/CENIT.

ECLAC (2012a). Structural Change for Equality: An Integrated Approach to Development, ECLAC, Santiago de Chile, Chile.

ECLAC (2012b). La inversión extranjera directa en América Latina y el Caribe 2011. CEPAL, Santiago de Chile, Chile.

ECLAC (2012c). Panorama de la inserción internacional de América Latina y el Caribe. CEPAL, Santiago de Chile, Chile.

Fajnzylber, Fernando (1990). "The United States and Japan as models of industrialization," in Gary Gereffi and Donald Wyman, eds., Manufacturing Miracles: Paths of Industrialization in Latin America and East Asia, Princeton: Princeton University Press: 323-353.

Fishlow, Albert, et. al. (1994). Miracle or Design: Lessons from the East Asian Experience. Overseas Development Council, Washington, DC.

Gallagher, Kevin P., and Daniel Chudnovsky (eds.) (2010). Rethinking Foreign Investment for Sustainable Development: Lessons from Latin America, London: Anthem Press.

Garrido, Celso, and Wilson Peres (1998). "Las grandes empresa y grupos industriales latinoamericanos en los anos noventa”, in W. Peres, ed., Grandes Empresas y Grupos Industriales Latinoamericanos, Siglo Veintiuno Editores and CEPAL, Mexico.

Gereffi, Gary, and Donald Wyman (eds.) (1990). Manufacturing Miracles: Paths of Industrialization in latin America and East Asia, Princeton Princeton University Press.

Haggard, Stephan (1990). Pathways from the Periphery. Cornell University Press, Ithaca.

Helleiner, Gerald K. (ed.) (1992). Trade Policy, Industrialization, and Development: New Perspectives, World Institute for Development Economics Research.

Kosacoff, Bernardo (ed.) (2000). Corporate Strategies under Structural Adjustment in Argentina. St. Martin's Press, New York.

Kuczynski, Pedro-Pablo, and John Williamson (eds.) (2003). After the Washington Consensus: Restar- 
ting Growth and Reform in Latin America, Washington, DC: Institute for International Economics.

Lall, Sanjaya, Manuel Albaldejo, and Mauricio Mesquita Moreira (2004). Latin American Industrial Competitiveness and the Challenge of Globalization. INTAL-ITD. Occasional Paper-SITI-05, Inter-American Development Bank, Washington, DC.

Moreno-Brid, Juan Carlos, and Igor Paunovic (2008). "What is New and What is Left of the Economic Policies of the New Left Governments of Latin America?" International Journal of Political Economy, v. 37, n. 3, Fall: 82-108.

Moreno-Brid, J.C., J.C. Rivas and J. Santamaría (2005). Mexico: Economic growth exports and industrial performance after NAFTA, Serie Estudios y perspectivas No. 42, Sede Subregional de la C E P A L en Mexico. CEPAL: Mexico.

Moreno-Brid, J.C., and J. Ros (2009). Development and Growth in the Mexican Economy: A Historical Perspective, Oxford: Oxford University Press.

Moreno-Brid, J.C., and J. Ros (2012). "The Mexican economy in 1960-2010: from import substitution and state-led industrialization to export-led slow growth", in L. Punzo, C. A. Feijoo and M. Puchet Anyul. eds., Beyond the Global Crisis, New York: Routledge.

Paus, Eva (2005). Foreign Investment, Development, and Globalization. Can Costa Rica Become Ireland? New York and London: Palgrave Macmillan.

Peres, Wilson. (2011). "Industrial policies in Latin America, UNU-Wider, Working Paper n. 2011/48, September.

Peres, Wilson (ed.) (1998). Grandes Empresas y Grupos Industriales Latinoamericanos. Siglo Ventiuno editors and CEPAL, Mexico.

Peres, Wilson, and Annalisa Primi (2009). "Theory and practice of industrial policy, evidence from the Latin American experience”, CEPAL, Santiago de Chile, February.

Shapiro, Helen (2011). "The pernicious legacy of the rent-seeking paradigm," in Shahrukh Khan and Jens Christiansen, eds., Towards New Developmentalism, London: Routledge.

Shapiro, Helen, and Lance Taylor (1990) "The State and industrial strategy", World Development 18(6): 861-78.

Shapiro, Helen (2007). "Industrial policy and growth," in Jose Antonio Ocampo, Jomo K.S. and Rob Vos, Growth Divergences, New York: Zed Books.

World Bank (1993). East Asian Miracle: Economic Growth and Public Policy. New York: Oxford University Press. 